\title{
Increasing loss of mature boreal forests around protected areas with red-listed forest species
}

\author{
Aino-Maija Määttänen ${ }^{*}(\mathbb{D}$, Raimo Virkkala@i], Niko Leikola@ and Risto K. Heikkinen (1)
}

\begin{abstract}
Background: Protected areas (PA) are central to biodiversity, but their efficiency is challenged by human-induced habitat loss and fragmentation. In the Fennoscandian boreal region, forestry with clearcutting is a threat to biodiversity causing the loss of mature forest elements and deterioration of ecological processes in forest landscapes, ultimately affecting PAs via declined structural connectivity. This paper aims to (1) determine PAs with high, red-listed species concentrations; (2) estimate the change in forest habitat around these PAs on different spatial scales; and (3) determine if forest management intensity is higher around biologically most valuable PAs. Occurrences of red-listed forest-dwelling species in Finland were used to identify PAs harbouring these species and to produce site-specific importance indices. CORINE landcover data was used as a baseline for the distribution of forests to assess the cover of clear-cuttings from 2001 to 2019 with the Global Forest Change (GFC) data set in three buffer areas around the PAs with occurrences of red-listed species.

Results: The largest proportion of clear-cuts occurred in $1 \mathrm{~km}$ and $10 \mathrm{~km}$ buffers around the PAs in the southern and middle boreal zones, being ca. 20\%. This indicates that the forest habitat is degrading fast at regional and landscape levels. On the positive side, the change in forest cover was lower around the biologically most important PAs compared to other PAs with red-listed species.

Conclusions: Open and free satellite-data based assessments of the cover and change of forests provide reliable estimates about the rates at which mature and old-growth forests are being converted into young managed ones in Finland mainly via clear-cuts on different scales around PAs. The rate of clear-cuts was lowest in adjacent buffer areas next to the most species-rich PAs, which provides opportunities for biodiversity conservation efforts to be targeted to the remaining mature and old-growth forests found in the vicinity of these areas.
\end{abstract}

Keywords: Biodiversity conservation, Boreal forest, Change detection, Global Forest Watch, Habitat loss, Structural connectivity

\section{Background}

Loss and degradation of natural habitats are the main drivers of the decline in biodiversity and the endangerment of species (Brooks et al. 2006; Haddad et al. 2015; Newbold et al. 2016). The decrease in the habitat area causes fragmentation, a consequence of which

*Correspondence: Aino-Maija.Maattanen@syke.fi

Biodiversity Centre, Finnish Environment Institute, Latokartanonkaari 11, 00790 Helsinki, Finland is that the remaining habitat occurs in smaller, more isolated patches embedded in a human modified landscape (Kouki et al. 2001; Hanski 2011). Importantly, the deterioration of habitat in the unprotected matrix can generate negative impacts on biodiversity values and ecophysiological conditions of protected areas (PA) themselves. These impacts are manifested as local-scale edge effects such as changes in light and moisture conditions and biotic disturbances (Moen and Jonsson 2003; Hansen and DeFries 2007), as well as lowered landscape-scale 
functionality of PAs caused by limitations for recolonisation, meta-population survival and migration (Haddad et al. 2015; Ward et al. 2020).

The expanding land use and exploitation of natural capital has resulted in two ecologically severe consequences: the global decline of natural habitats' intactness and the loss of structural and functional connectivity between PAs, given that only ca. $10 \%$ of PAs are connected through intact landscapes (Ward et al. 2020). As a response, enhanced conservation efforts across all biomes have been initialised to safeguard functioning ecosystems and their biodiversity. For example, the 2020 strategic Plan for Biodiversity and the EU's biodiversity strategy 2030 recognise the invaluable role of biodiversity for sustainable development. An important goal in these initiatives is that the PA network should not only cover a certain proportion of land or sea area but also that the PAs should be ecologically representative and well connected to support the target of a green infrastructure (CBD 2010; European Commission 2013, 2020; Ward et al. 2020).

Structural connectivity is a key landscape-scale feature of habitat and PA networks when assessing the impacts of habitat loss (Ward et al. 2020). It defines the spatial arrangement and relationship of elements in the physical landscape (e.g., forest habitat patches). Both observational and experimental studies have revealed that a decrease in structural connectivity affects species trends, although ecosystem responses may occur more slowly than land cover changes (Haddad et al. 2015).

Global assessments have suggested that land-use impacts on biodiversity in a circumboreal boreal zone are, on average, smaller than elsewhere (Newbold et al. 2016) and that the boreal forest biome has remained relatively intact compared to other forest biomes (Brooks et al. 2006; Ward et al. 2020; Mikusiński et al. 2021). However, global scale analyses do not recognise the fragmentation that has taken place in Finland and other Fennoscandian countries, because the landscape transformation has generally been a replacement of old-growth forests and other naturally regenerated forests by young managed production forests (Kouki et al. 2001; Elbakidze et al. 2013; Koivula and Vanha-Majamaa 2020). The boreal forests in Fennoscandia have experienced intensive management with clear-cuttings and an increase in even-aged forest stands especially since the mid-1900s. This has caused a significant fragmentation of natural forest habitats and altered their temporal continuity (Kouki et al. 2001; Svensson et al. 2019; Jonsson et al. 2019), causing the endangerment of demanding forest-dwelling species (Tikkanen et al. 2006; Tingstad et al. 2018). Moreover, while the amount and cover of protected areas has increased, larger PAs have predominantly been located in the less productive areas, such as in Northern Finland and in the mountain range region in Sweden (Virkkala and Rajasärkkä 2007; Elbakidze et al. 2013; Svensson et al. 2019). Thus, isolated forested PAs situated in human-transformed areas of Fennoscandia are exposed to the impacts of accumulating habitat loss and decrease in structural connectivity in their surroundings, with potential harmful effects carried over to the PAs themselves (Hansen and DeFries 2007; Virkkala et al. 2020). Since the amount of natural old-growth forest is scarce it is important to also safeguard the managed forests that have achieved a mature successional stage and have old-growth characteristics (Kuuluvainen and Gaulthier 2018). In Finland, such valuable mature forest consist of closed-canopy forests with a stand age of $60-120$ years depending on the site type and location in the country.

A common tool for assessing the extent of the habitat loss in the matrix around the PAs is space-borne remote sensing (RS), which is also applied in this study. Following the increase in accessibility and temporal continuity of earth observation data, image analysis applications are frequently used for evaluating the state of and changes in the environment and acquiring environmental information for decision making. Considering forest protection, such information can facilitate the determination of where remaining intact habitats are located and where conservation priorities should be targeted, as well as where habitat fragmentation risks are most forceful (Svensson et al. 2020). In this work, we focused on PAs with red-listed forest species to study the changes in forest extent and matrix quality. These red-listed forest species are, in general, susceptible to increased forest harvesting with forestry and other forest use being the main cause of their decline (Hyvärinen et al. 2019).

Our main study objectives were: (1) to determine the most important forested sites within the current protected area network which include concentrations of selected red-listed forest species; (2) to examine how the forest matrix has changed during the last 19 years around the PAs with red-listed species using open geospatial land use and land cover classification data based on satellite imagery, and whether the changes in forest cover show up differently on different spatial scales; and (3) to assess whether the top $5 \%$ of PAs with the most valuable occurrences of red-listed forest species have experienced more habitat loss in their surroundings than other PAs with red-listed species.

\section{Methods}

Protected area polygons were downloaded from Parks and Wildlife Finland's geographic information system ULJAS (SATJ) in September of 2019. The data included all PAs on government-owned and privately owned areas, 
wilderness areas and areas that are designated to be future PAs. To eliminate any overlap between these conservation types and to establish the true borders between protected and the surrounding non-protected matrix, all polygons in the raw data were dissolved together. PA polygons smaller than 0.1 hectares in size with no forest cover or no red-listed forest species observations were excluded because these areas were mostly islands in the Baltic Sea. Such areas would not contribute to the analysis of forest change around PAs but would increase the computation times of the analyses. Additionally, we opted for enough raster pixels to be fit inside the polygons to guarantee credible quantifications of the forest area and its change. The resulting dataset consisted of 16,315 PA polygons ranging from 0.01 to 670,000 hectares in size. The studied PAs were assigned to and analysed in the three different forest vegetation zones: the southern boreal (also including the hemiboreal zone), the middle boreal and the northern boreal zone (see Fig. 1, Table 1).

Around each PA polygon, three buffers of $100 \mathrm{~m}, 1 \mathrm{~km}$ and $10 \mathrm{~km}$ were created. These buffers were employed to measure the change in forest cover occurring on different scales around the PAs. The smallest $100 \mathrm{~m}$ buffer represents a local scale and reflects the changes occurring along the edge of the PA or in its immediate vicinity. The $1 \mathrm{~km}$ buffer encompasses landscape-scale patterns in forest management, whereas the $10 \mathrm{~km}$ buffer reflects largescale regional trends in forest cover changes. The three scales also provide a rough link to species groups with different dispersal potential (see, e.g., Økland et al. 1996; Similä et al. 2006).

Observations of red-listed forest-dwelling species were acquired from three sources: the Finnish Biodiversity Information Facility (FinBIF), Parks and Wildlife Finland's geographic information system, ULJAS (LajiGIS), and the Finnish Environment Institute's Hertta information system. The data are based on presence-only observations from species monitoring campaigns, sample collections and citizen observations. All observations of selected species with a spatial accuracy of $100 \mathrm{~m}$ or finer that were recorded between the 1st of January 1990 and 30 th of July 2020 were included in the analysis. We considered all species groups except birds because the data

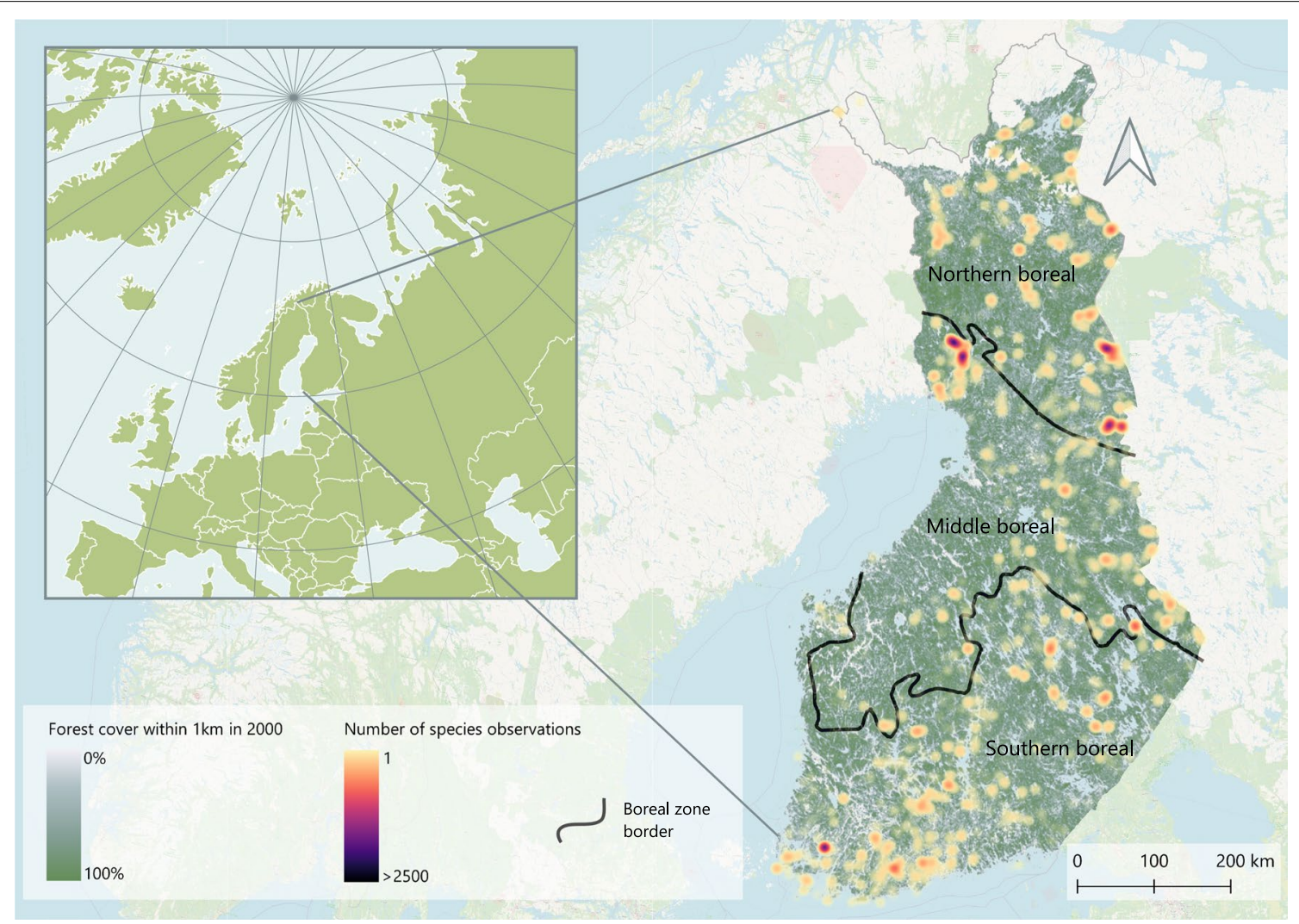

Fig. 1 The study area, Finland, and the three boreal forest vegetation zones. The background of the map shows the amount of forest habitat (from CORINE 2000 database) visualised using a $1 \mathrm{~km}$ moving window, and the agglomerations of the red-listed forest species occurrences in the current protected area network overlaid on the background map with a $10 \mathrm{~km}$ kernel density heat map 
Table 1 Mean values ( \pm standard error) in the proportion of forests clear-cut in 2000-2019 in the buffer zones around RFPAs (PAs where red-listed forest species were observed) and their significance between the different forest vegetation zones

\begin{tabular}{|c|c|c|c|c|c|c|c|c|c|c|c|}
\hline \multirow[t]{2}{*}{ Buffer zone } & \multicolumn{3}{|c|}{ Forest vegetation zone } & \multicolumn{2}{|c|}{ Test statistic } & \multicolumn{2}{|c|}{$\begin{array}{l}\text { Southern boreal } \\
\text { vs. middle } \\
\text { boreal }\end{array}$} & \multicolumn{2}{|c|}{$\begin{array}{l}\text { Southern boreal } \\
\text { vs. northern } \\
\text { boreal }\end{array}$} & \multicolumn{2}{|c|}{$\begin{array}{l}\text { Middle boreal } \\
\text { vs. northern } \\
\text { boreal }\end{array}$} \\
\hline & $\begin{array}{l}\text { Southern boreal } \\
(\%) \\
(n=2330)\end{array}$ & $\begin{array}{l}\text { Middle boreal } \\
(\%) \\
(n=811)\end{array}$ & $\begin{array}{l}\text { Northern boreal } \\
(\%) \\
(n=197)\end{array}$ & $z$ & $P$ & $z$ & $P$ & $z$ & $P$ & $z$ & $P$ \\
\hline $100 \mathrm{~m}$ & $15.04 \pm 0.33$ & $14.98 \pm 0.50$ & $9.36 \pm 0.70$ & 21.139 & $<0.001$ & 2.287 & 0.022 & 3.624 & $<0.001$ & 4.559 & $<0.001$ \\
\hline 1 km & $19.37 \pm 0.21$ & $17.67 \pm 0.28$ & $11.00 \pm 0.53$ & 151.157 & $<0.001$ & 4.923 & $<0.001$ & 11.850 & $<0.001$ & 8.543 & $<0.001$ \\
\hline 10 km & $22.10 \pm 0.13$ & $18.24 \pm 0.14$ & $9.84 \pm 0.29$ & 850.836 & $<0.001$ & 20.956 & $<0.001$ & 23.058 & $<0.001$ & 10.783 & $<0.00$ \\
\hline
\end{tabular}

Statistical significance based on Kruskal-Wallis one-way analysis of variance $(K=3)$ with a posteriori tests. Bonferroni-adjusted significance level $(P=0.017)$ in the pairwise comparisons

of bird observations with sufficient accuracy was very scarce. Moreover, we focused on the species primarily inhabiting mature or old-growth forests and excluded species that thrive equally well in forests with semi-open canopy and shrubby habitats. The primary habitat of each species was confirmed based on information derived from online species databases (e.g., https://www.slu.se/ en/research/research-excellence/research-infrastruc ture/databaser-och-biobanker/species-database/) and relevant literature on ecological species requirements. Thus, we excluded species which were described as equally often sparsely wooded, semi-open habitats such as sunny grasslands with bushes than more forested habitats. This enabled us to focus on forest species for which clear fellings cause a loss of suitable habitat, although the degree of dependency on interior forest conditions, such as humidity, light and temperature and wind, ultimately determine the severity of this impact (Tikkanen et al. 2006). The full list of the species that were included in the analysis is available in the Additional file 1: Table S1.

Because the locations of some species observations were recorded as the coordinates of the left corner of a sampling quadrant, the positions of all species records with a coarser spatial accuracy than $1 \mathrm{~m}$ were corrected and averaged to their centre locations. Duplicate points between different datasets were excluded. The final occurrence data contained 177,831 records of 864 redlisted species across different taxa. Of these 75,760 observations (42.6\%) of 756 red-listed species were recorded in protected areas. A $100 \times 100 \mathrm{~m}$ grid was draped over the occurrence points and their information was spatially joined to the $100 \mathrm{~m}$ square they fell into. Summed information was established for each $100 \mathrm{~m}$ square about the number of species and number of observations they harboured using an FCS biological records tool (version 3.3.0) in QGIS.

We created an importance index of red-listed species to assess the importance of each occurrence site for each species. First, for all individual species, a percentage of occurrences in each $100 \mathrm{~m}$ square was calculated. If the focal species was absent in a square, its value was 0 and if all the species occurrences were inside the same square the value was 100 . In the second step, the total square importance was determined as the sum of percentages of species present in a square. All calculations were carried out in R (R Core Team 2014). In the third step, all species data in the squares that intersected or were located within a protected area were grouped and passed onto each PA polygon. In this way, we gathered information for each PA polygon on the number of red-listed species it contained and how important it was as a habitat for the studied red-listed species. Because the $100 \times 100 \mathrm{~m}$ square was only requested to intersect, and not be completely within a PA, the results may be over-estimations. However, the over-estimation is systematic across PAs and treating the intersection in this manner allowed us to incorporate species observations with a coarser geographic accuracy than $1 \mathrm{~m}$ into the analysis. The number of PAs where one or more red-listed forest species were recorded (hereafter RFPAs) was 3338 with areas ranging from 0.108 to 670,670 ha (the total protected area of RFPAs was 3,725,950 ha). In comparison, our study species were not observed in 12,977 protected areas (NPAs hereafter) ranging from 0.1 to 15,590 ha and summing up to 641,487 ha.

The forest cover and extent in the year 2000 were determined using the CORINE Land Cover classification (hereafter CLC2000) system with a spatial resolution of $25 \mathrm{~m}$. The Finnish Environment Institute (SYKE) is responsible for the data production for CLC in Finland. We opted to use CORINE CLC2000 data because the thematic resolution of the data allows easy delineation between forest and non-forest areas. The selected land cover classes were broad-leaved forests, coniferous forests, mixed forests and transitional woodlands where the canopy cover was $>10 \%$. The starting point, i.e. the forest 
distribution raster with all forest classes distribution in the year 2000 was reclassified into a binary format where the value 1 represented a pixel where forest was the primary landcover and 0 represented all other land covers.

Forest cover inside protected areas and the three buffers was determined as the sum of an intersecting area of forest cells. The forest area in RFPAs was an average of (mean \pm standard error) $398.0 \pm 105.2$ ha (ranging from 0 ha to $2721.06 \mathrm{~km}^{2}$ ) but only $16.3 \pm 0.7$ ha in NPAs (ranging from 0 ha to $4295 \mathrm{~km}^{2}$ ) reflecting the huge variation in the size of the PAs. The forest area in the $100 \mathrm{~m}, 1 \mathrm{~km}$ and $10 \mathrm{~km}$ buffers in the year 2000 around RFPAs was, on average, $43.4 \pm 2.4,517.0 \pm 19.7$ and 19,501.5 $\pm 166.0 \mathrm{ha}$, and around NPAs, $12.0 \pm 0.2$, $233.6 \pm 2.1$ and $12,818.3 \pm 46.4$ ha, respectively.

The areas where a change in forest cover had occurred between 2001 and 2019 were identified using the Global Forest Change (hereafter GFC) Forest Loss layer data (version 1.7) (Hansen et al. 2013). The GFC raster data set is based on the Landsat missions' imagery. It detects areas previously identified as forest that have been transformed into non-forest due to human-induced change such as clear-cuttings or changes in the land cover type, or natural causes such as forest fires or wind disturbance. The data shows areas of forest loss over 19 years from the year 2001 onwards with a cell value of 1-19 according to the year the loss was identified (Hansen et al. 2013). The forest cover change was calculated by subtracting the pixels appointed as a loss according to the GFC data from the starting point forest distribution raster image.

We acknowledge here two factors which may affect the interpretation of the results. First, there is a wellknown biogeographic trend of species richness diminishing from south to north which can affect the number of old-growth forest species recorded from the PAs in different parts of the country. Second, in Finland the largest protected areas occur in the northern boreal forest vegetation zone, which makes taking their inventories more labour-intensive. Thus, due to the spatially skewed species data distributions affecting the importance index results in thew PAs, the changes in forest cover around the most important areas were examined for the main south-to-north biogeographic (southern, middle and northern boreal) zones separately. PAs were ranked according to their red-listed species importance index and then the 95th percentile of PAs that showed the highest index values were selected separately from the three forest vegetation zones. This division was made so that all vegetation zones would be represented in the analysis of how intensive forest management is around these valuable areas. There were 117, 41 and 10 top 5\% RFPAs with the most valuable species occurrences in the southern, middle and northern boreal zones, respectively.
A comparison of changes in forest areas primarily due to (see Additional file 1: Appendix S1) clear-cuts in 2001-2019 around the RFPAs in the three buffers and between the three forest vegetation zones was done using non-parametric tests: a Mann Whitney $U$-test, a Kruskal-Wallis one-way analysis of variance or a Friedman's two-way analysis of variance. Continuous forest cover maps were created from the binary forest distribution raster images for the years 2000 and 2019 with moving window averages using $100 \mathrm{~m}, 1 \mathrm{~km}$ and $10 \mathrm{~km}$ window sizes. These raster images were used to visualise the mean proportion of forest cover change at all three different scales between the years 2001 and 2019.

Our primary focus was on the overall change in forest cover between 2001 and 2019, but we also provide an assessment of temporal changes from 2001 to 2005, 2006 to 2010, 2011 to 2015 and 2016 to 2019, in the Additional file 1 . However, recent studies have indicated that the temporal trends determined from GFC data need caution because of certain inconsistencies, particularly the increased change detection ability from Landsat imagery (Ceccherini et al. 2020; Ceccherini et al. 2021; Palahí et al. 2021). In SI, while reporting the temporal trends in forest cover change we thus provide in-depth discussions on how these uncertainties are likely to affect the temporal forest change assessments by GFC in Finland and whether the different underlying causes of forest cover change and associated GFC inconsistencies matter considering the ecological implications for red-listed forest species.

Another source of uncertainty in the forest cover trend assessments based on GFC data are natural disturbances. Risks of misinterpretation of natural disturbances such as man-made harvesting are apparent in certain areas in central and southern Europe, where disturbances can constitute a notable part of the forest area loss detected by the GFC data (Palahí et al. 2021; but see Ceccherini et al. 2021). By comparison, in our study area, natural disturbances such as wildfires or storms occur only occasionally and the total amount of forest loss resulting from them is small compared to the cover of clear-cut forest area. More precisely, storms felled altogether 26 million $\mathrm{m}^{3}$ of wood in Finland from 2001 to 2019 (Viiri et al. 2019). In the same time period, the total logging volume was 1200 million $\mathrm{m}^{3}$ (yearly mean 63.2 million $\mathrm{m}^{3}$, Natural Resources Institute Finland). Thus, wind-felled trees comprised $2.2 \%$ of the logging volume in our study period. Forest fires are efficiently suppressed in Finland, and from 2005 to 2018, fires covered, on average, only an area of $7.0 \mathrm{~km}^{2}$ of forest annually (Statistics Finland 2020 ), which is less than $0.5 \%$ of the yearly area of clearcuts in Finland (about $1500 \mathrm{~km}^{2}$, Natural Resources Institute Finland). Moreover, in ecological terms, the ultimate 
outcome in the natural disturbance sites outside the PA network is often similar to terminal harvesting. This is because most of the trees felled by storms or in fire areas in the matrix are actually removed from the disturbed forest stands and thus no additional sources of dead wood, for example, are left on the sites. Thus, the management of natural disturbance areas can contribute to the loss of forest habitat and connectivity in the production forest matrix.

\section{Results}

In all three buffers around RFPAs, the change in forest area in 2001-2019 differed significantly between the forest vegetation zones so that it was highest in the southern boreal and smallest in the northern boreal zone (Figs. 2 and 3 , Table 1$)$. The main effects were highly significant $(P<0.001)$ in the different buffers between the vegetation zones with $z$-values between 21.139 and 850.836. All pairwise comparisons in the buffers between the forest vegetation zones, except between the southern and the middle boreal zone in the $100 \mathrm{~m}$ buffer (based on Bonferroni correction), were statistically significant (Table 1).

A higher proportion of forests around RFPAs were clear-cut further away from the PA in the $10 \mathrm{~km}$ buffer than close by within the $100 \mathrm{~m}$ buffer or the $1 \mathrm{~km}$ buffer. This trend was most apparent in the southern and middle boreal zones (Fig. 2, Tables 1 and 2). Additionally, in the northern boreal zone a higher proportion of forests were clear-cut in the $1 \mathrm{~km}$ and $10 \mathrm{~km}$ buffers than in the

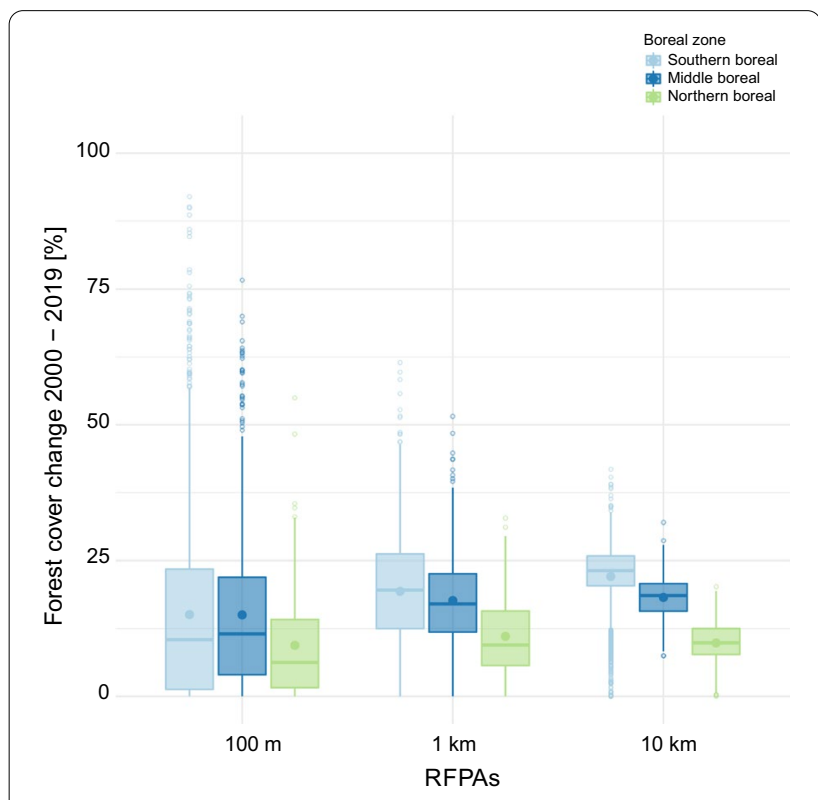

Fig. 2 Cumulative forest cover change percentages in the three boreal zones between 2001 and 2019 and in the three buffer zones around the PAs with occurrences of red-listed forest species
$100 \mathrm{~m}$ buffer (Fig. 2, Tables 1 and 2). On average, the highest mean forest loss was $22.1 \%$ in the $10 \mathrm{~km}$ buffer in southern boreal zone corresponding to 3884.3 hectares, and the lowest mean loss $9.36 \% 19$ hectares in the $100 \mathrm{~m}$ buffer in the northern boreal zone (Table 1). However, the largest variation in the level of forest change appeared in the $100 \mathrm{~m}$ buffer GCF data, indicating that there are numerous RFPAs where more than half of the forest land in their immediate surroundings had been clear-cut (Fig. 2).

When the forest change data are further visualised using the moving-window averages, the resulting maps show a clear gradient from north to south. This gradient shows the variation in the intensity of forest harvesting which is particularly apparent in the map based on the $10 \mathrm{~km}$ buffer data (Fig. 3). The decline in intensity from south to north is also apparent when the percentage of clear-cuts around $1 \mathrm{~km}$ of the RFPAs is plotted against latitude (Additional file 1: Fig. S4).

High numbers of observations of red-listed forest species were recorded in PAs situated in different parts of the country, in all three boreal zones (Fig. 1). Red-listed species were particularly concentrated on the southern and southwestern coast, as well as the inlands of central Finland, where the most productive herb-rich forests with many threatened species are more common. In the middle boreal and northern boreal zone, the highest concentrations of observations of red-listed species were in PAs consisting of highly valuable coniferous dominated old-growth forests (Fig. 1). We compared our red-listed species importance index also with with different PA characteristics like PA size (Additional file 1: Fig. S5), accessibility (Additional file 1: Fig. S6) and how much protected forest was within $1 \mathrm{~km}$ buffer around the PA (Additional file 1: Fig. S7). Furthermore, the most threatened species seemed to be generally concentrated in the same PAs as detected by our species importance score (Additional file 1: Fig. S8).

The same PAs are even more highlighted when RFPAs were ranked based on the species importance index. Four examples of highly valuable RFPAs and the forest loss in their surroundings are shown in Fig. 4: Ruissalo in the southwestern coast presents a PA with specific oak and herb-rich forest species, Pisavaara Strict Nature Reserve and Oulanka National Park are important areas of northern old-growth forests, and Kakonsalo is a PA with southern boreal species of old-growth forests. As a comparison, when the value of the species importance index was standardized according to the PA size, RFPAs situated in the southern boreal zone often received a higher value due to their smaller size (Additional file 1: Fig. S1). However, it is important to note that there was a huge variation both in red-listed 


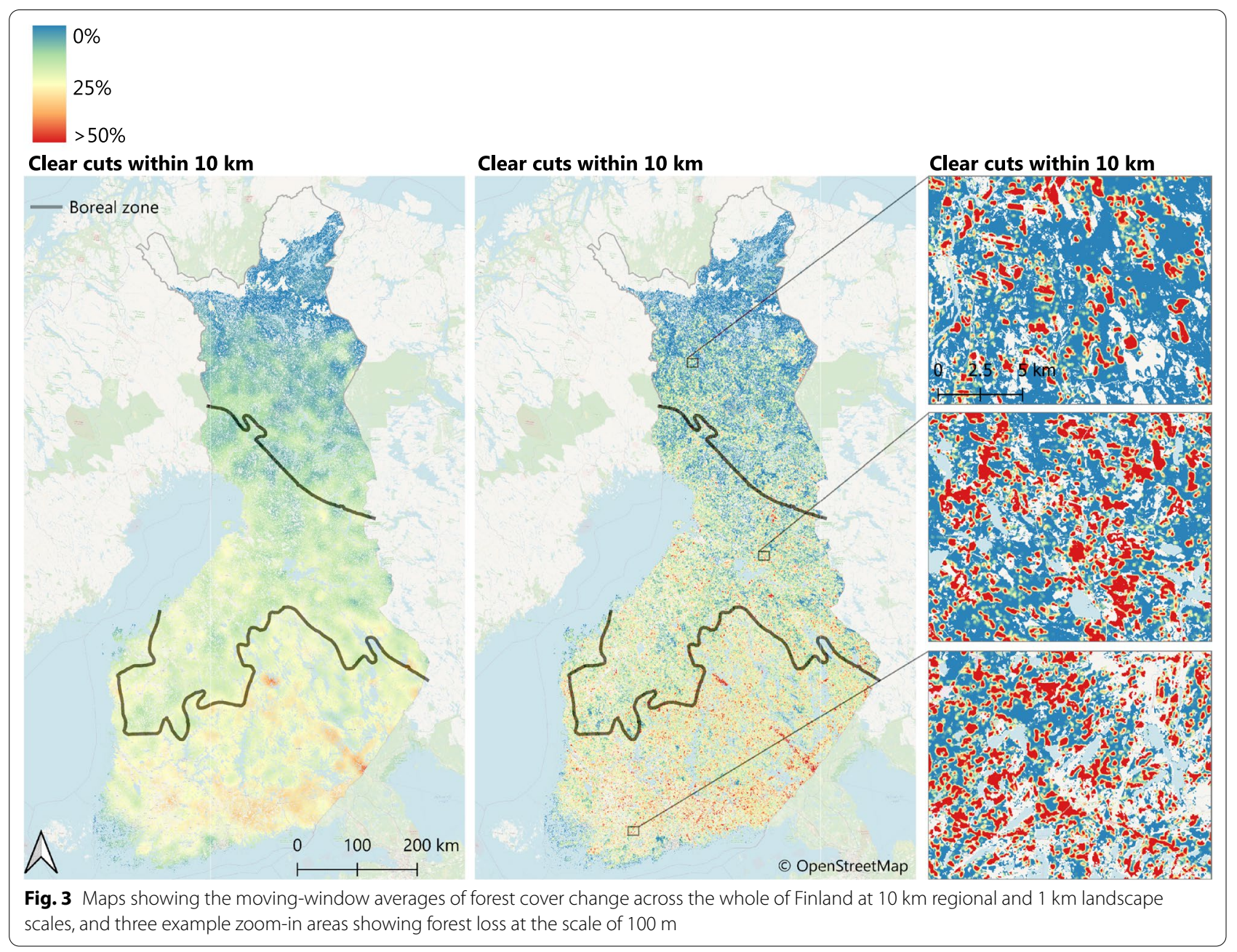

Table 2 Significance in the proportion of forests clear-cut in 2000-2019 between the different buffer zones around RFPAs

\begin{tabular}{|c|c|c|c|c|c|c|c|c|}
\hline \multirow[t]{2}{*}{ Forest vegetation zone } & \multirow[t]{2}{*}{ Test statistic } & \multirow[t]{2}{*}{$P$} & \multicolumn{2}{|c|}{$100 \mathrm{~m}$ vs. 1 km } & \multicolumn{2}{|c|}{$100 \mathrm{~m}$ vs. $10 \mathrm{~km}$} & \multicolumn{2}{|c|}{$1 \mathrm{~km}$ vs. $10 \mathrm{~km}$} \\
\hline & & & $z$ & $P$ & $z$ & $P$ & $z$ & $P$ \\
\hline Southern boreal & 923.635 & $<0.001$ & 18.209 & $<0.001$ & 30.023 & $<0.001$ & 11.814 & $<0.001$ \\
\hline Middle boreal & 169.514 & $<0.001$ & 9.733 & $<0.001$ & 12.353 & $<0.001$ & 2.620 & 0.009 \\
\hline Northern boreal & 40.161 & $<0.001$ & 6.046 & $<0.001$ & 4.610 & $<0.001$ & 1.436 & 0.151 \\
\hline
\end{tabular}

Statistical test based on Friedman's non-parametric two-way analysis of variance $(K=3)$ with a posteriori tests between the buffer zones. Values of change $(\%)$ in each buffer zone in each forest vegetation zone and number of RFPAs in each vegetation zone presented in Table 1 . Bonferroni adjusted significance level $(P=0.017)$ in the pairwise comparisons

species' richness and in the red-listed species importance index between the RFPAs in all three boreal zones (Additional file 1: Fig. S2). Here, we concentrate on the absolute values of species importance instead of the standardized ones, because they provide a more straightforward demonstration of the spatial distribution of highly valuable forest PAs. More information about the selected metric and its relationship with different PA properties are explored in the Additional file 1.

Examination of the changes in the forest cover around the RFPAs with the highest 5\% species importance index values showed that the forest loss in the buffers of the top 5\% RFPAs was, on average, lower than for the other RFPAs (Fig. 5, Table 3). This indicates that the clear fellings around the most species observation-rich RFPAs 


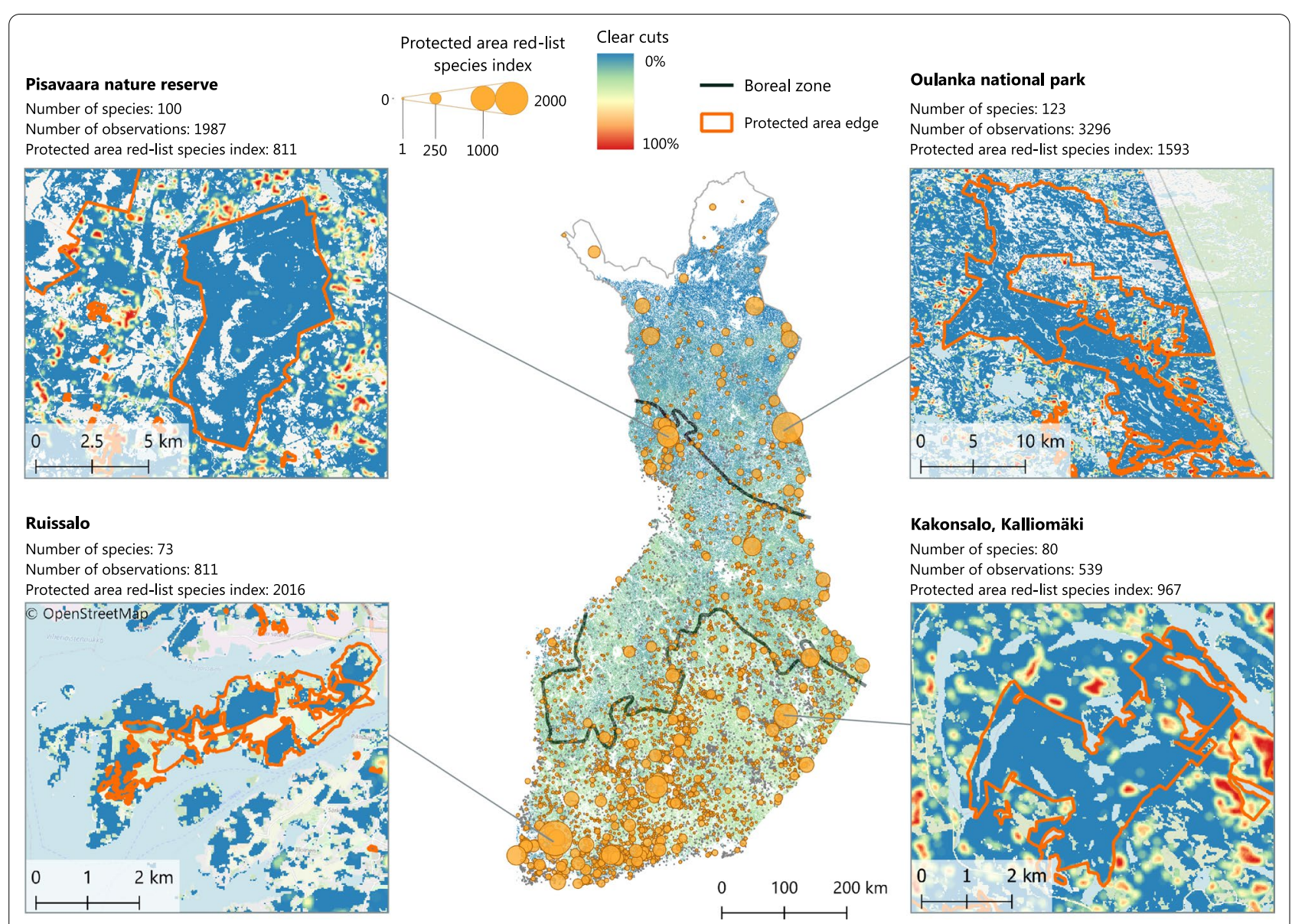

Fig. 4 The highest values of summed red-listed species importance indices and the forest change percentage at a $10 \mathrm{~km}$ window and at a $100 \mathrm{~m}$ window. The white spaces are other land cover than forest

have been less severe than around the other RFPAs, with this trend being constant in all three buffers and all three boreal forest zones.

Our results suggest that there was a significant difference in the change of forest cover between the four consecutive periods in 2001-2019 (Additional file 1: Fig. S3) both in the $1 \mathrm{~km}$ and in the $10 \mathrm{~km}$ buffers within all the boreal zones (Friedman's two-way ANOVA, $P<0.001$, $z$-values between 17.852 and 3098.372, Additional file 1: Table S2), predominantly reflecting increasing forest harvesting. In contrast, in the $100 \mathrm{~m}$ buffer only in the southern boreal zone was there a significant change of forest cover between the four periods $(z=45.925, P<0.001$, Additional file 1: Table S2).

\section{Discussion}

\section{Recent forest cover change in Fennoscandia}

This study shows that during the last 20 years, protected areas with red-listed forest species in Finland have experienced increasing isolation and degradation of matrix quality, primarily due to the clear-cutting of unprotected mature forests, and to a minor extent, other forest management activities and tree felling storms. The corresponding trend of continued forest clear-cutting and the resulting fragmentation of forest landscapes have also been reported for Sweden (Svensson et al. 2019; Angelstam et al. 2020). As a long-term outcome, intensive and wide-spread forestry with clear fellings in Fennoscandia have caused a major loss of natural forest habitats, longlasting detrimental impacts of forest biota dependent on intact forest conditions and a decline in the habitat quality and structural and functional connectivity of PAs (Tikkanen et al. 2006; Felton et al. 2020; Mikusiński et al. 2021).

We assessed the loss of mature forests around PAs at the regional and landscape level using $10-\mathrm{km}$ and $1-\mathrm{km}$ buffers around the PAs. At these scales, the forest landscape in Finland has experienced considerable degradation and related fragmentation due to increased forest harvesting during 2000-2019, which can severely obstruct the climate-change-induced movements of redlisted forest species that require mature or old-growth 


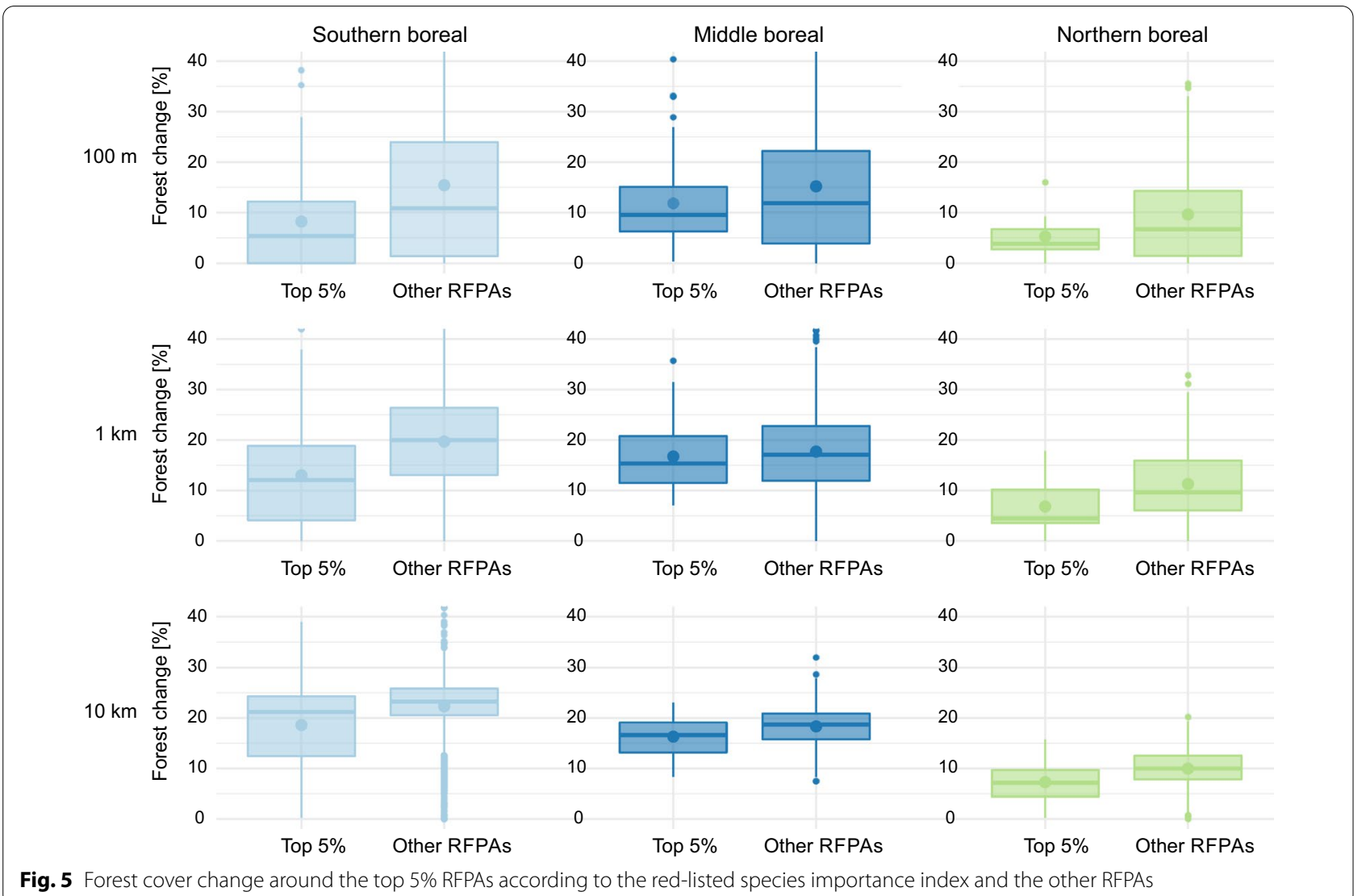

Fig. 5 Forest cover change around the top 5\% RFPAs according to the red-listed species importance index and the other RFPAs

Table 3 Mean ( \pm standard error) percent values of forests clear-cut in the different buffer zones in 2000-2019 in the RFPAs with highest values in the red-listed species index (top 5\%) and in the other RFPAs

\begin{tabular}{|c|c|c|c|c|c|}
\hline Forest vegetation zone & Buffer zone & Top $5 \%$ of RFPAs & Other RFPAs & $z$ & $P$ \\
\hline \multirow[t]{3}{*}{ Southern boreal } & $100 \mathrm{~m}$ & $8.15 \pm 0.89$ & $15.41 \pm 0.35$ & 4.637 & $<0.001$ \\
\hline & $1 \mathrm{~km}$ & $13.03 \pm 0.97$ & $19.71 \pm 0.22$ & 6.758 & $<0.001$ \\
\hline & $10 \mathrm{~km}$ & $18.61 \pm 0.75$ & $22.29 \pm 0.13$ & 4.928 & $<0.001$ \\
\hline \multirow[t]{3}{*}{ Middle boreal } & $100 \mathrm{~m}$ & $11.78 \pm 1.43$ & $15.15 \pm 0.52$ & 0.792 & 0.428 \\
\hline & $1 \mathrm{~km}$ & $16.74 \pm 1.08$ & $17.71 \pm 0.29$ & 0.843 & 0.399 \\
\hline & $10 \mathrm{~km}$ & $16.31 \pm 0.60$ & $18.34 \pm 0.14$ & 3.145 & 0.002 \\
\hline \multirow[t]{3}{*}{ Northern boreal } & $100 \mathrm{~m}$ & $5.26 \pm 1.45$ & $9.57 \pm 0.73$ & 1.006 & 0.314 \\
\hline & $1 \mathrm{~km}$ & $6.83 \pm 1.74$ & $11.23 \pm 0.55$ & 1.862 & 0.063 \\
\hline & $10 \mathrm{~km}$ & $7.29 \pm 1.37$ & $9.98 \pm 0.30$ & 2.112 & 0.035 \\
\hline
\end{tabular}

Number of RFPAs in the southern boreal, middle boreal and northern boreal zone were 117,41 and 10 in the top $5 \%$ of RFPAs and 2213,770 and 187 in the other RFPAs, respectively. Statistical test by Mann-Whitney U-test

forest conditions to survive (e.g. Virkkala et al. 2013). In the southern and middle boreal zones of Finland, the proportion of forests clear-cut was, on average, about $20 \%(18-22 \%)$ in the $1 \mathrm{~km}$ and $10 \mathrm{~km}$ buffers. This means that practically all forests outside PAs may be clear-cut during the rotation cycle (70-100 years depending on site type) in areas where the PAs still harbour important biota but are threatened due to their small size and the low overall cover of the PA network. In the northern boreal zone, $10-11 \%$ of forests in the $1 \mathrm{~km}$ and $10 \mathrm{~km}$ buffers were clear-cut. However, here the rotation cycle is longer (100-140 years) and a much higher proportion of forests are protected (17\% of forest land, Virkkala and Rajasärkkä (2007)) than in the southern or middle boreal 
zone (less than 5\%) resulting in a lower proportion of managed and unprotected forests in the buffer areas.

\section{Ecological impacts of local-scale forest loss and decreasing landscape-level connectivity}

Protected areas are linked to their immediate and landscape-scale surroundings via different ecological impacts and processes ranging from altered eco-physiological conditions and community composition all the way to inhibited species movements (Hamilton et al. 2013). The immediate land use around the PAs can notably affect the effectiveness of PAs to safeguard endangered species populations (Haddad et al. 2015). For forested PAs, negative impacts of land use in the adjacent surroundings include certain carryover impacts, particularly increased edge effects influencing the microclimate within the PA, and increased exposure to human impacts (Hylander et al. 2004; Ruete et al. 2016). Such edge effects can be a particularly significant threat for small-sized PAs where sensitive red-listed species will face the impacts of reduced interior core habitat (Moen and Jonsson 2003; Aune et al. 2005).

In our results, the proportion of forests that were clearcut was, on average, smaller in the $100 \mathrm{~m}$ buffer than in the buffers of $1 \mathrm{~km}$ and $10 \mathrm{~km}$. However, among the 3338 PAs with red-listed species, there were 532 PAs (16\%) which experienced over $30 \%$ loss in the forest cover in their $100 \mathrm{~m}$ buffer areas. In order to retain red-listed species which are sensitive to the edge effects in these 532 PAs, enhanced biodiversity-friendly forest restoration may be required for their surroundings. On the other hand, logging levels in areas adjacent to PAs have been less intensive than in the wider landscape. This provides the potential for the future enlargement of PAs with valuable biota or targeting-enhanced biodiversity-friendly forest management practices in their surroundings. For the small PAs, such enlargements are highly recommendable because they are at risk due to the edge effects, and because of the sensitivity of small-sized populations to local extinctions (e.g., Cheptou et al. 2017; Wootton and Pfister 2013).

Intensified land use in the wider landscape around the PAs can also pose many impacts on the persistence of red-listed species in individual PAs as well as in the PA network. Deterioration of the habitat in the matrix can make the surrounding landscape more hostile. In essence, species with specialised habitat requirements will have increased difficulties in finding suitable habitats in the matrix, and consequently, face increased challenges retaining their source/sink dynamics in suitable areas (Hansen and DeFries 2007; Haddad et al. 2015; Ward et al. 2020).

\section{Red-listed forest species and declining matrix quality}

Accumulating loss and fragmentation of natural forest biotopes due to increasing anthropogenic pressures have caused the widespread decline of structural connectivity in Fennoscandian boreal forests (Felton et al. 2020; Mikusiński et al. 2021), as well as an alarming endangerment of the forest biota (Tikkanen et al. 2006; Tingstad et al. 2018). A key concern in conserving forest biodiversity under continuous habitat loss is how detrimental the impact of contemporary rotational management with clear fellings is for different types of red-listed species and what the necessary elements are in the production forest matrix which would support critical ecological mechanisms and facilitate functional connectivity for ecologically demanding species (Ward et al. 2020). What may crucially determine species responses is how effectively they can benefit from the elements that are retained during forest harvesting, i.e. elements conserved in retention forestry (Koivula and Vanha-Majamaa 2020).

The exact habitat requirements for successful population maintenance in forest landscapes are not fully understood for many species (Kouki et al. 2001). However, recent research has provided useful general information across species groups. Clearly, species that have difficulties surviving in rotationally clear-cut forests are those that depend on larger patches of intact forest with large, old trees, a humid microclimate and abundant coarse woody debris, including forest bird species (Virkkala 2004), moss and hepatics species (Moen and Jonsson 2003), specialised wood-inhabiting fungi (Abrego et al. 2017) and certain epiphytic lichen species (Tikkanen et al. 2006). In contrast, certain red-listed beetle (Coleoptera) species are thermophilous and thrive in clear-cuts if a sufficient number of retention trees are left (Tikkanen et al. 2006). Thus, it is especially the humid interior forest species which intensively managed production forest landscapes provide very few suitable habitats, causing a crucial decrease of functional connectivity (Tikkanen et al. 2006; Angelstam et al. 2020). Moreover, enhanced management measures, such as leaving higher quantities of dead wood and larger retention trees in larger and denser stands than are left under the current practices would be required to truly mitigate the decline of endangered forest biota (Tikkanen et al. 2006; Gustafsson et al. 2010; Koivula and Vanha-Majamaa 2020). This would also require to be further complemented by extended harvesting rotation lengths (Roberge et al. 2018).

\section{Assessing forest loss with remote sensing techniques}

In our analyses at the $25 \mathrm{~m}$ resolution, the GFC data performed well in recognizing clear cut areas. Like any derivatives of remotely sensed data, the GFC and CLC 
data sets are subject to misclassification due to spectral mixing and other resolution-related issues. According to the pixel-based validation using high resolution historical aerial images, presented in Additional file 1: Appendix S1, misclassification occurred mainly on sites where extensive thinning had taken place. Resolution-wise GFC data are best suited to recognising changes occurring uniformly on large scales, such us our buffers of $1 \mathrm{~km}$ and $10 \mathrm{~km}$ around PAs. Higher-resolution satellite imagery such as IKONOS or Geo-Eye reaching sub-meter resolutions have the potential to reveal different spatial and statistical patterns compared to the ones recorded at coarser resolutions, such as the one used here (Wickham and Riitters 2019). Thus, it is probable that finer resolution land cover data could increase the total forest area in the matrix due to the increased visibility of small forest patches. However, finer resolution data could also produce increased visibility of other land cover classes and reveal that the structure of the forest area is actually more fragmented than initially considered especially in the $100 \mathrm{~m}$ buffer (Kouki et al. 2001; Wickham and Riitters 2019).

As highlighted in recent studies (Palahí et al. 2021; Ceccherini et al. 2021) and discussed in more depth in the Additional material (Additional file 1: Appendix S1, Fig. S3), temporal comparisons of forest cover change based on the GFC data must be made with caution due to certain technical inconsistencies in Landsat image analysis. Therefore, we compared the large recent years' increase in forest harvesting levels in our landscape-scale results with the forestry statistics of Finland, which show that the total clear-cut areas have indeed increased by $15 \%$ in 2016-2019 compared to 2011-2015 (Natural Resources Institute Finland). Additionally, more generally, logging volumes have increased in Europe, and most forcefully so in Northern Europe (FOREST EUROPE 2020). Thus, although some amount of thinnings and selective cuttings may have been misinterpreted as clear-cuts in GFC data, the general trend of increased forest harvesting suggested by GFC data appears to be correct.

\section{Conclusions}

Global scale analyses of habitat intactness tend to underestimate the intensively managed and thus structurally fragmented nature of Fennoscandian boreal forests. However, the free and open landcover and land change derivatives of the medium resolution Landsat imagery used in this study showed that especially at landscape scales the Fennoscandian forest habitat has been substantially transformed from natural and oldgrowth forest into young and managed forest mainly via clear-cutting. Our estimates of declining oldgrowth and mature forest areas and the straightforward ranking of PAs by their importance as species habitats suggest that as pressure for expanding the area under conservation increases, any existing mature forests right outside PAs should be prioritized in order to safeguard red-listed species in the future.

\section{Abbreviations}

CLC: CORINE Land Cover; GFC: Global Forest Change; NPA: Protected area, where red-listed species were not observed; PA: Protected area; RFPA: Protected area, where red-listed species were observed; RS: Remote sensing.

\section{Supplementary Information}

The online version contains supplementary material available at https://doi. org/10.1186/s13717-022-00361-5.

Additional file 1: Appendix S1. Temporal trends in forest cover change around the studied protected areas. Table S1. List of species. Table S2. The change of forest cover between the four consecutive periods around the protected areas with red-listed forest species. Figure S1. Summed red-listed species importance index standardised by the size of the protected area. Figure S2. Scatterplot of the number of red-listed forest species in the protected areas in relation to latitude. Figure S3. Temporal trends of forest clear fellings around the protected areas with red-listed forest species occurrences. Figure S4. Scatterplot of the RFPA area and red-list species index. Figure $\mathbf{S 5}$. Scatterplot of PA size and the sum of red-listed species importance. Figure S6. Scatterplot of RFPA distance to nearest road and red-list species index. Figure S7. Scatterplot of the amount of protected forest within $1 \mathrm{~km}$ from the RFPA and red-list species index. Figure S8. Ranking RFPAs based on IUCN classes of species observed within them.

\section{Acknowledgements}

We wish to thank the two anonymous reviewers whose helpful comments helped to improve this manuscript. This work was supported by the Ministry of the Environment of Finland through SUMI and FEO projects.

\section{Author contributions}

A-MM and NL collected the data. A-MM performed the data analysis, visualisations and led the writing of the text in collaboration with the other authors. RV and $\mathrm{RH}$ were responsible for the acquisition of funding and project management. RV conducted the statistical tests and prepared the tables. $\mathrm{RH}$ pruned the list of focal species. All authors contributed to the conceptualisation of the study design as well as read and critiqued the manuscript. All authors read and approved the final manuscript.

\section{Funding}

This work was supported by funding provided by the Finnish Ministry of the Environment (Evaluating the protected area network in the changing climate, SUMI, and the Finnish Ecosystem Observatory, FEO), and the Strategic Research Council (SRC) at the Academy of Finland (Decision No 312559).

\section{Availability of data and materials}

The datasets supporting the conclusions of this article are publicly available from providers. Global Forest Change data is available in: https://earthengin epartners.appspot.com/science-2013-global-forest/download_v1.7.html. CORINE Land Cover 2000 dataset is available in: https://ckan.ymparisto.fi/datas et/\%7BA70BC25F-43A2-4C33-A42D-9C22D9D4A3DB\%7D. The use of sensitive data of red-listed species observations is restricted to scientific research due to which only aggregated observations are openly available to the public. Data in its original form can be requested from the Finnish Biodiversity Information Facility (FinBIF). Our species list can be found under Administrative status filter and named Connectivity of forest conservation areas - SUMI Project 2020: https:// laji.fi/en/taxon/list?onlyFinnish=true\&adminStatusFilters=MX.finnishEnvironm entInstitute2020conservationProjectSpecies. 


\section{Declarations}

Ethics approval and consent to participate

Not applicable.

\section{Consent for publication}

All authors gave their consent for publication.

\section{Competing interests}

The authors have no financial or proprietary interests in any material discussed in this article.

Received: 23 August 2021 Accepted: 17 January 2022

Published online: 20 February 2022

\section{References}

Abrego N, Dunson D, Halme P, Salcedo I, Ovaskainen O (2017) Wood-inhabiting fungi with tight associations with other species have declined as a response to forest management. Oikos 126:269-275. https://doi.org/10. 1111/oik.03674

Angelstam P, Manton M, Green M, Jonsson BG, Mikusiński G, Svensson J, Sabatini FM (2020) Sweden does not meet agreed national and international forest biodiversity targets: a call for adaptive landscape planning. Landsc Urban Plan 202:103838. https://doi.org/10.1016/j.landurbplan. 2020.103838

Aune K, Jonsson BG, Moen J (2005) Isolation and edge effects among woodland key habitats in Sweden: is forest policy promoting fragmentation? Biol Conserv 124:89-95. https://doi.org/10.1016/j.biocon.2005.01.015

Brooks TM, Mittermeier RA, da Fonseca GAB, Gerlach J, Hoffmann M, Lamoreux JF, Mittermeier CG et al (2006) Global biodiversity conservation priorities. Science 313(5783):58-61. https://doi.org/10.1126/science.1127609

CBD (2010) Convention on Biological Diversity strategic plan for biodiversity 2011-2020 and the Aichi targets. Convention on Biological Diversity, Montreal. https://www.cbd.int/sp/targets/. Accessed 4 Apr 2021

Ceccherini G, Duveiller G, Grassi G, Lemoine G, Avitabile V, Pilli R, Cescatti A (2020) Abrupt increase in harvested forest area over Europe after 2015 Nature 583:72-77. https://doi.org/10.1038/s41586-020-2438-y

Ceccherini G, Duveiller G, Grassi G, Lemoine G, Avitabile V, Pilli R, Cescatti A (2021) Reply to Wernick, I. K. et al.; Palahí, M. et al. Nature 592:E18-E23. https://doi.org/10.1038/s41586-021-03294-9

Cheptou PO, Hargreaves AL, Bonte D, Jacquemyn H (2017) Adaptation to fragmentation: evolutionary dynamics driven by human influences. Philos Trans R Soc B 372:20160037. https://doi.org/10.1098/rstb.2016.0037

Elbakidze M, Angelstam P, Sobolev N, Degerman E, Andersson K, Axelsson R, Höjer O, Wennberg S (2013) Protected area as an indicator of ecological sustainability? A century of development in Europe's boreal forest. Ambio 42:201-214. https://doi.org/10.1007/s13280-012-0375-1

European Commission (2013) Green infrastructure (Gl)_enhancing Europe's natural capital. Communication from the commission to the European Parliament, the Council, the European Economic and Social Committee and the Committee of the regions. $\operatorname{COM}(2013) 249$, Brussels

European Commission (2020) Biodiversity strategy for 2030: bringing nature back into our lives. Communication to the European Parliament, the Council, the European Economic and Social Committee and the Committee of the regions. $\operatorname{COM}(2020) 380$, Brussels

Felton A, Löfroth T, Angelstam P, Gustafsson L, Hjältén J, Felton AM, Simonsson P, Dahlberg A et al (2020) Keeping pace with forestry: multi-scale conservation in a changing production forest matrix. Ambio 49:1050-1064. https://doi.org/10.1007/s13280-019-01248-0

FOREST EUROPE (2020) State of Europe's forests 2020. https://foresteurope. org/state-europes-forests-2020/

Gustafsson L, Kouki J, Sverdrup-Thygeson A (2010) Tree retention as a conservation measure in clear-cut forests of northern Europe: a review of ecological consequences. Scand J For Res 25:295-308. https://doi.org/10. 1080/02827581.2010.497495

Haddad NM, Brudvig LA, Clobert J, Davies KF, Gonzalez A, Holt RD, Lovejoy TE, Sexton JO et al (2015) Habitat fragmentation and its lasting impact on earth's ecosystems. Sci Adv 1(2):e1500052. https://doi.org/10.1126/sciadv 1500052

Hamilton CM, Martinuzzi S, Plantinga AJ, Radeloff VC, Lewis DJ, Thogmartin WE et al (2013) Current and future land use around a Nationwide protected area network. PLoS ONE 8(1):e55737. https://doi.org/10.1371/journal. pone.0055737

Hansen AJ, DeFries R (2007) Ecological mechanisms linking protected areas to surrounding lands. Ecol Appl 17:974-988. https://doi.org/10.1890/ 05-1098

Hansen MC, Potapov PV, Moore R, Hancher M, Turubanova SA, Tyukavina A, Thau D, Stehman SV et al (2013) High-resolution global maps of 21stcentury forest cover change. Science 342(6160):850-853. https://doi.org/ $10.1126 /$ science. 1244693

Hanski I (2011) Habitat loss, the dynamics of biodiversity, and a perspective on conservation. Ambio 40(3):248-255. https://doi.org/10.1007/ s13280-011-0147-3

Hylander K, Nilsson C, Göthner T (2004) Effects of buffer-strip retention and clearcutting on land snails in boreal riparian forests. Conserv Biol 18:1052-1062. https://doi.org/10.1111/j.1523-1739.2004.00199.x

Hyvärinen E, Juslén A, Kemppainen E, Uddström A, Liukko UM (eds) (2019) The 2019 Red List of Finnish species. Ministry of the Environment \& Finnish Environment Institute. Helsinki, Finland (in Finnish with English summary). http://hdl.handle.net/10138/299501

Jonsson BG, Svensson J, Mikusiński G, Manton M, Angelstam P (2019) European Union's last intact forest landscapes are at a value chain crossroad between multiple use and intensified wood production. Forests 10(7):564. https://doi.org/10.3390/f10070564

Koivula M, Vanha-Majamaa I (2020) Experimental evidence on biodiversity impacts of variable retention forestry, prescribed burning, and deadwood manipulation in Fennoscandia. Ecol Process 9:11. https://doi.org/10.1186/ s13717-019-0209-1

Kouki J, Löfman S, Martikainen P, Rouvinen S, Uotila A (2001) Forest fragmentation in Fennoscandia: linking habitat requirements of wood-associated threatened species to landscape and habitat changes. Scand J For Res 16(S3):27-37. https://doi.org/10.1080/028275801300090564

Kuuluvainen T, Gauthier S (2018) Young and old forest in the boreal: critical stages of ecosystem dynamics and management under global change. For Ecosyst 5:26. https://doi.org/10.1186/s40663-018-0142-2

Mikusiński G, Orlikowska EH, Bubnicki JW, Jonsson BG, Svensson J (2021) Strengthening the network of high conservation value forests in boreal landscapes. Front Ecol Evol 8:486. https://doi.org/10.3389/fevo.2020. 595730

Moen J, Jonsson BG (2003) Edge effects on liverworts and lichens in forest patches in a mosaic of boreal forest and wetland. Conserv Biol 17:380388. https://doi.org/10.1046/j.1523-1739.2003.00406.x

Newbold T, Hudson LN, Arnell AP, Contu S, De Palma A, Ferrier S, Hill SLL, Hoskins AJ et al (2016) Has land use pushed terrestrial biodiversity beyond the planetary boundary? A global assessment. Science 353(6296):288-291. https://doi.org/10.1126/science.aaf2201

Økland B, Bakke A, Hågvar S, Kvamme T (1996) What factors influence the diversity of saproxylic beetles? A multiscaled study from a spruce forest in southern Norway. Biodivers Conserv 5(1):75-100

Palahí M, Valbuena R, Sent C, Acil N, Pugh TAM, Sadler J, Seidl R, Potapov P et al (2021) Concerns about reported harvests in European forests. Nature 592:E15-E17. https://doi.org/10.1038/s41586-021-03292-x

R Core Team (2014) R: a language and environment for statistical computing. $R$ Foundation for Statistical Computing, Vienna, Austria. http://www.R-proje ct.org/

Roberge JM, Öhman K, Lämås T, Felton A, Ranius T, Lundmark T, Nordin A (2018) Modified forest rotation lengths: long-term effects on landscapescale habitat availability for specialized species. J Environ Manag 210:1-9. https://doi.org/10.1016/j.jenvman.2017.12.022

Ruete A, Snäll T, Jönsson M (2016) Dynamic anthropogenic edge effects on the distribution and diversity of fungi in fragmented old-growth forests. Ecol Appl 26:1475-1485. https://doi.org/10.1890/15-1271

Similä M, Kouki J, Mönkkönen M, Sippola AL, Huhta E (2006) Co-variation and indicators of species diversity: can richness of forest-dwelling species be predicted in northern boreal forests? Ecol Indic 6(4):686-700

Statistics Finland (2020) Greenhouse gas emissions in Finland 1990 to 2018. National Inventory Report under the UNFCCC and the Kyoto Protocol, Helsinki 
Svensson J, Andersson J, Sandström P, Mikusiński G, Jonsson BG (2019) Landscape trajectory of natural boreal forest loss as an impediment to green infrastructure. Conserv Biol 33(1):152-163. https://doi.org/10.1111/cobi. 13148

Svensson J, Bubnicki JW, Jonsson BG, Andersson J, Mikusiński G (2020)

Conservation significance of intact forest landscapes in the Scandinavian Mountains Green Belt. Landsc Ecol 35:2113-2131. https://doi.org/10. 1007/s10980-020-01088-4

Tikkanen OP, Martikainen P, Hyvärinen E, Junninen K, Kouki J (2006) Red-listed boreal forest species of Finland: associations with forest structure, tree species, and decaying wood. Ann Zool Fenn 43:373-383

Tingstad L, Grytnes JA, Felde VA, Juslén A, Hyvärinen E, Dahlberg A (2018) The potential to use documentation in national Red Lists to characterize red-listed forest species in Fennoscandia and to guide conservation. Glob Ecol Conserv 15:e00410. https://doi.org/10.1016/j.gecco.2018.e00410

Viri H, Viitanen J, Mutanen A, Leppänen J (2019) Metsätuhot vaikuttavat Euroopan puumarkkinoihin—Suomessa vaikutukset toistaiseksi vähäisiä (In Finnish). Metsätieteen aikakauskirja 2019, 10200. https://doi.org/10. $14214 /$ ma. 10200

Virkkala R (2004) Bird species dynamics in a managed southern boreal forest in Finland. For Ecol Manag 195:151-163. https://doi.org/10.1016/j.foreco. 2004.02.037

Virkkala R, Rajasärkkä A (2007) Uneven regional distribution of protected areas in Finland: consequences for boreal forest bird populations. Biol Conserv 134:361-371. https://doi.org/10.1016/j.biocon.2006.08.006

Virkkala R, Heikkinen RK, Fronzek S, Kujala H, Leikola N (2013) Does the protected area network preserve bird species of conservation concern in a rapidly changing climate? Biodivers Conserv 22:459-482. https://doi.org/ 10.1007/s10531-012-0423-y

Virkkala R, Lehikoinen A, Rajasärkkä A (2020) Can protected areas buffer short-term population changes of resident bird species in a period of intensified forest harvesting? Biol Conserv 244:108526. https://doi.org/10. 1016/j.biocon.2020.108526

Ward M, Saura S, Williams B, Ramírez-Delgado JP, Arafeh-Dalmau N, Allan JR, Venter $O$ et al (2020) Just ten percent of the global terrestrial protected area network is structurally connected via intact land. Nat Commun 11:4563. https://doi.org/10.1038/s41467-020-18457-x

Wickham J, Riitters KH (2019) Influence of high-resolution data on the assessment of forest fragmentation. Landsc Ecol 34(9):2169-2182. https://doi. org/10.1007/s10980-019-00820-z

Wootton JT, Pfister CA (2013) Experimental separation of genetic and demographic factors on extinction risk in wild populations. Ecology 94:2117-2123. https://doi.org/10.1890/12-1828.1

\section{Publisher's Note}

Springer Nature remains neutral with regard to jurisdictional claims in published maps and institutional affiliations.

\section{Submit your manuscript to a SpringerOpen ${ }^{\circ}$ journal and benefit from:}

- Convenient online submission

- Rigorous peer review

- Open access: articles freely available online

- High visibility within the field

- Retaining the copyright to your article 